\title{
Op pad na optimale ondersteuning vir akademiese geletterdhede: Die strewe na beter belyning tussen teorie en praktyk
}

\author{
Ydalene Coetsee \\ Taalsentrum, Universiteit Stellenbosch, Suid-Afrika \\ E-pos: yc@sun.ac.za
}

\section{Opsomming}

Een van die Universiteit Stellenbosch (US) Taalsentrum se waardevolste bydraes sedert die ontstaan daarvan is 'n verbeterde belyning tussen teorie en praktyk vir die fasilitering van akademiese geletterdhede (AG). 'n Dekade gelede het die taalmatige ondersteuning wat die US aan veral eerstejaars verleen het, nog uit generiese modules bestaan waarvolgens studente tekste gelees en geproduseer het na gelang van dosentevoorkeur. Sedertdien het die literatuur 'n aansienlike verskuiwing in die rigting van ingebedde modules teweeg gebring. In hierdie sin beteken ingebed dat studente in elke vakgebied slegs met temas, tekste en genres te doen kry wat op die spesifieke vakgebied van toepassing is. Alhoewel Taalsentrumpersoneel aanvanklik traag was om hierdie verskuiwing te aktualiseer, meestal weens die ekonomie van skaal, het hulle die afgelope paar jaar vakspesifieke en pasklaar kursusse vir studente in die meeste USfakulteite ontwikkel en gefasiliteer. Hierdie soort herkurrikulering word nie altyd na waarde geskat nie aangesien die verskil in impak moeilik is om kwantitatief te meet. In die meeste gevalle moet Taalsentrumpersoneel ook met personeel van US-fakulteite saamwerk wat neig om vaardighede in AG in 'n laerstatuskategorie (sagte vaardighede) as wetenskapvaardighede (harde vaardighede) te plaas. Hierdie studie ondersoek een so 'n geval van samewerking tussen die Taalsentrum en die Departement Chemie en Polimeerwetenskap aan die US, die sogenaamde Pet Ionic Compound (PIC)-projek. Innovasiefondssteun is verkry ten einde die uitkomste van AG en dié van die Departement Chemie en Polimeerwetenskap in die vakgebied chemie op so 'n manier te integreer dat optimale sukses vir studente in die verlengde graadprogram nagestreef kon word. Hierdie artikel doen verslag oor die impak van sodanige samewerking vir die afgelope drie iterasies van die projek en poog om 'n bydrae te lewer tot die literatuur oor die uitwerking van teoretiese begronding op die praktyk van AG. Verskillende studente- en dosentetekste is deur middel van oop kodering ontleed om die impak van hierdie projek op studente se waargenome kennis van chemie, asook hulle ontwikkeling met betrekking tot AG kwalitatief te meet. Die artikel probeer verder ekspliseer dat alhoewel hierdie soort samewerking tyd en inspanning verg, dit die moeite werd geag behoort te word indien studenteen dosentesukses daardeur geoptimaliseer kan word.

Trefwoorde: akademiese geletterdhede, chemie, ingebed, samewerking, teoretiese ontwikkeling 


\title{
The road to optimal academic literacies support: Striving for better alignment between theory and practice
}

\begin{abstract}
One of the Stellenbosch University (SU) Language Centre's most valuable contributions since its inception has been the endeavour of striving towards better alignment between theory and practice for the facilitation of academic literacies. A decade ago, SU's language support to mainly first-year students used to be generic modules according to which texts were read and produced by students in line with the preferences of lecturers. Since then, literature has documented a significent shift in the direction of embedded modules, meaning that students only deal with themes and genres applicable to their specific discipline. Although Language Centre staff were initially slow in actualising this shift, mainly because of the economy of scale, over the past few years they have developed and facilitated subject-specific and purpose-made modules in most SU faculties. The time and effort spent on this kind of reconceptualisation is not always estimated in its true value, as the full impact thereof is difficult to measure quantitatively. Moreover, in most instances Language Centre staff have to collaborate with SU faculty staff who tend to categorise academic literacy skills as lower category skills (soft skills), compared to scientific skills (hard skills). This study focuses on one such a case of collaboration between the Language Centre and the Department of Chemistry and Polymer Science at SU, the so-called Pet Ionic Compound (PIC) project. Innovation fund support was obtained in order to integrate the outcomes of academic literacies and those of the Department of Chemistry and Polymer Science in the field of chemistry in such a way as to ensure improved learning for students in extended degree programmes. This article reports on the impact of such collaboration over the past three iterations of the project and aims to supplement the literature on the effect of theoretical grounding on academic literacies practice. Various student and lecturer documents were analysed through open coding to undertake a qualitative measurement of the impact of this specific project on students' perceived knowledge of chemistry and their academic literacies development. The article also endeavours to explicate that although this kind of collaboration requires time and effort, such collaboration should be encouraged in an attempt to optimise student and lecturer success.
\end{abstract}

Keywords: academic literacies, chemistry, collaboration, embedded, theoretical development

\section{Inleiding}

Wêreldwyd poog hoëronderwysinstellings om tred te hou met ontwikkelings in die teoretiese begronding van vakgebiede. Om hierdie konstante verandering verder te problematiseer word akademici wat oor dissiplinêre, institusionele en nasionale grense heen wetenskap bedryf, gedurig uitgedaag wat die jongste ontwikkelings op interdissiplinêre gebiede betref. Boonop verander studente wat tot hoëronderwysinstellings toegelaat word se profiel, vaardighede en graduandi-eienskappe voortdurend.

Een van die waardevolste akademiese bydraes wat die Universiteit Stellenbosch (US) Taalsentrum $^{1}$ die afgelope dekade gelewer het, was die ontwikkeling van modules vir

1 By die Universiteit Stellenbosch (US) word modules in AG deur die Taalsentrum aangebied in fakulteite wat dit aanvra, meestal vir eerstejaarstudente. 
akademiese geletterdhede (AG) in byna alle US-fakulteite. Die uitkomste van hierdie modules was oorspronklik gebaseer op die sogenaamde vaardigheidsbenadering wat studente se gebrek aan vaardighede aangetoon het en as antwoord daarop gepoog het om in dié gebrek te voorsien. Hierdie teoretiese benadering is egter die afgelope tyd agterhaal ten gunste van die benadering dat studente ' $n$ bydrae te maak het in die generering van nuwe kennis. Hierdie artikel ondersoek die impak van dié ontwikkeling, asook ander ontwikkelings in die teorie oor AG op die praktyk van die Taalsentrum se AG-modules. Tekste van een module, te wete Wetenskapskommunikasievaardigheid 146, is longitudinaal (2010-2016) ondersoek om te bepaal of die ontwikkeling in teorie wel in die praktyk waarde toegevoeg het. Oop kodering van studentetekste is eerstens aangepak om persepsies oor die waarde daarvan te ondersoek, en tweedens is gestruktureerde vraelyste gebruik om dosente se persepsies oor die belyning tussen teorie en praktyk te probeer kwantifiseer.

In die eerste deel van die artikel word 'n opsomming van die ontwikkeling in teoretiese benaderings ten opsigte van AG aangebied as konteks vir die veranderings wat die praktyk van die spesifieke module in die afgelope paar jaar ondergaan het. Om die impak van die spesifieke module op studente longitudinaal aan te toon, was teoreties gesproke waarskynlik eenvoudiger in 2010 as vandag, soos hier onder aangetoon sal word. Die verandering in die praktyk tot op die huidige vierde iterasie van een spesifieke intervensie (die sogenaamde PIC-projek) word vervolgens bespreek, waarna die metodologie, bevindings en gevolgtrekkings onder die loep kom.

\section{Ontwikkeling van teorie}

Vorige literatuurondersoeke, veral oor die feit dat AG verkieslik in vakdissiplines ingebed moet wees (Jacobs 2010) en nie as generiese modules eenders vir alle eerstejaars aangebied moet word nie, het reeds die vernaamste teoretiese ontwikkelings aangetoon. Weens die beperkte aard van die afgebakende studie word daar dus gefokus op die mate waarin die Taalsentrum op teoretiese ontwikkelings gereageer het.

Akademiese geletterdheid (let op die enkelvoud hier) is jare lank gesien as die vermoë om akademies te skryf (byvoorbeeld om 'n sekere soort essay of eksamenantwoord te produseer). Die aanname dat dit eenvoudig is om aan te toon hoe om akademies te skryf en hoe om die vaardigheid vir studente aan te leer, was egter altyd problematies. Die eksplisering van verskillende subvaardighede soos hoe om inligting uit bronne te integreer, hoe om te parafraseer, of hoe om na bronne te verwys, was reeds deel van akademiese skryfwerk, maar inligtingsvaardighede (hoe om gepaste bronne te soek), visuele geletterdheid, gesyferdheid (numeracy) en tegnologiese vaardighede (hoe om elektroniese toestelle akademies in te span) is saam met kritiese denkvaardighede noodsaaklik vir sukses op universiteit. Taalvaardighede is dus slegs enkele van die vaardighede wat noodsaaklik is vir akademiese sukses. Boonop kan daar aangetoon word dat taal slegs die voertuig van abstrakte denke is en nie 'n afsonderlike soort kennis is nie. Die ontwikkeling van die konstruk 'Akademiese Geletterdhede' (AG) (Lillis en Scott 2007) het onder andere die problematisering van ontbrekende taalvaardighede wat min of meer sonder moeite (Lea en Street 2006:369) bygevoeg kan word, ten doel gehad.

Reeds in 1979 het Cummins (2008:71-83) aangetoon dat daar wat taal betref 'n verskil bestaan tussen basiese interpersoonlike kommunikatiewe vaardighede en vaardighede wat vir akademiese werk benodig word (CALP, of Cognitive Academic Language Proficiency). Dit is nodig om te leer hoe om hierdie akademiese diskoers te voer - 'n diskoers wat radikaal van 
vakgebied tot vakgebied verskil en selfs as aparte tale beskou kan word wat studente van nuuts af moet aanleer. Voorheen is die gebrek aan CALP ook gesien as 'n manier om "minder geletterdes" (sogenaamde underprepared students) van die akademie uit te sluit. Die massifisering van hoër onderwys het egter tot gevolg gehad dat meer en meer studente sonder sekere basiese vermoëns om akademies te lees en skryf op universiteit opgedaag het. Hier is hulle getoets en die vaardighede wat hulle kortgekom het, is geïdentifiseer in ' $n$ poging om hulle so gou moontlik gereed te kry vir akademiese skryfwerk. Hierdie manier van dink ontken die konstruksie van kennis as deel van sosiale praktyke wat in spesifieke kontekste ingebed is (Jacobs 2013:130).

Aangesien AG-modules by die US generies vir meestal eerstejaars aangebied is, is daar in die verlede gepoog om tekste, opdragte en assesserings vir alle eerstejaars relevant te maak. Op die evalueringsvorms is sodanige materiaal egter soms aangedui as nie relevant vir byvoorbeeld gesondheidswetenskappe- of teologiestudente nie (sien opmerkings oor relevansie, bylaag B). Om geletterdheidsmodules meer relevant te maak, het sommige instellings later spesifieke genres (soos navorsingsverslae) by module-uitkomste gevoeg om materiaal minder generies en meer vakspesifiek te maak. Hierdie ontwikkeling het dit deels ten doel gehad om die status en geloofwaardigheid van geletterdheidsmodules vir studente en vakspesialiste te verhoog, maar primêr ook steeds om studente taalmatig optimaal vir hulle ander modules te bemagtig.

Hierdie studie fokus op wetenskapskommunikasievaardighede vir studente in die natuurwetenskappe en ingenieurswese wat saam vir modules in die verlengde graadprogram geregistreer is.

Een van die eerste teoretiese verskuiwings wat aangedui kan word, is dié ten opsigte van AGmodules wat voorheen apart van vakmodules gekonseptualiseer is. Om vakkennis tesame met geletterdheidsontwikkeling aan te bied, is egter meer effektief (Jacobs 2010; Carstens 2013). Heelwat navorsing dien reeds as aanbeveling vir die verskuiwing van silomodules na ingebedde modules, wat noue samewerking tussen geletterdheid- en vakspesialiste veronderstel (sien French 2011 vir 'n uitgebreide lys).

Die inbed van AG in fakulteite word in die literatuur op 'n kontinuum vanaf content-integrated language learning (Wolff 2003) tot slegs ' $n$ vae beduidenis van vakdissipline-inhoud aangedui. Hierdie studie poog om 'n bydrae te lewer tot werklike samewerking tussen AG-dosente (verbonde aan die Taalsentrum) en dosente (verbonde aan die Departement Chemie en Polimeerwetenskap) betrokke by die vakgebied chemie vanaf die konsepsie van 'n projek tot en met die afhandeling van navorsing daaroor.

Een van die gevolge van die verskuiwing vanaf spesifieke vaardighede (die deficit model, sien ook Smit 2012) na geletterdhede as sosialisering in vakgebiede (Henderson en Hirst 2007) is dat dit heelwat moeiliker geword het om die impak van geletterdheidsmodules te meet. Verder is noue samewerking tussen dosente in $\mathrm{AG}$ en dosente uit die onderskeie vakgebiede noodsaaklik vir hierdie soort ingebedde modules om suksesvol te wees, aangesien vakkennis geëkspliseer moet word op maniere wat studente kan verstaan, soms deur AG-dosente wat nie oor sodanige vakkennis beskik nie (Jacobs 2013).

Opsommenderwys word die vernaamste teoretiese verskuiwings in AG vir die afbakening van hierdie spesifieke studie in tabel 1 weergegee. In 2010 is daar begin met die AG-module wat in hierdie studie ondersoek word. Die konstruk van AG wat toe gebruik is (Weideman 2003) en 
met behulp van die Toets van Akademiese Geletterdheidsvlakke (TAG)/Test of Academic Literacy Levels (TALL) getoets is, was nie deurgaans belyn met die verwagtings van die fakulteit, die uitkomste van die module, die werk wat in die klas gefasiliteer is en die formatiewe assesserings nie (soos later aangetoon sal word). Besluite hieroor is dikwels in studenteterugvoer gekritiseer en toetse is soms as irrelevant beskou. In tabel 1 word daar gepoog om die vernaamste verskille tussen die teoretiese begronding van AG in 2010 en 2017 uit te wys.

Tabel 1: Teoretiese verskuiwings vir AG (vereenvoudig)

\begin{tabular}{|l|l|l|}
\hline \multicolumn{1}{|c|}{ Primêre fokus van AG teen 2010 } & Primêre fokus van AG teen 2017 & \multicolumn{1}{|c|}{ Kommentaar } \\
\hline $\begin{array}{l}\text { Vaardigheidsontwikkeling } \\
\text { (positivistiese benadering tot leer) } \\
\text { Konstruk van Weideman (2003) } \\
\begin{array}{l}\text { generiese benadering ([vir alle studente } \\
\text { dieselfde materiaal]) }\end{array}\end{array}$ & $\begin{array}{l}\text { Sosialisering in vakgebiede (Gee 1996; } \\
\text { Hirst et al. 2004) } \\
\text { konstruktivistiese benadering) }\end{array}$ & \\
\hline $\begin{array}{l}\text { Fokus op instelling se persepsie van } \\
\text { studentebehoeftes }\end{array}$ & $\begin{array}{l}\text { Fokus op studente: op ware behoeftes } \\
\text { vir akademiese en beroepsukses, maar } \\
\text { ook op wat hulle kan bydra tot die } \\
\text { leerproses (Boughey en McKenna 2016) }\end{array}$ & $\begin{array}{l}\text { Verskil tussen outonome en } \\
\text { ideologiese benadering tot } \\
\text { AG }\end{array}$ \\
\hline $\begin{array}{l}\text { Fokus op skryfwerk, soms ook } \\
\text { taalvermoë genoem in literatuur (Van } \\
\text { Dyk et al. 2011; Van Dyk en Van der } \\
\text { Slik 2012) }\end{array}$ & $\begin{array}{l}\text { Verskillende geletterdhede is ter sprake; } \\
\text { taal is slegs die medium (Boughey 2013; } \\
\text { Lea 2004; Lea en Street 2006) }\end{array}$ & $\begin{array}{l}\text { Geletterdheidsvereistes vir } \\
\text { die akademie is velerlei en } \\
\text { implisiet }\end{array}$ \\
\hline $\begin{array}{l}\text { AG as alleenstaande module } \\
\text { Geen samewerking met fakulteite }\end{array}$ & $\begin{array}{l}\text { AG ingebed in vakdissiplines (Jacobs } \\
\text { 2009, 2010, 2013) }\end{array}$ & $\begin{array}{l}\text { Eksplisering van vakkennis - } \\
\text { die rol van AG-dosent }\end{array}$ \\
\hline $\begin{array}{l}\text { AG-spesialisgebied ondergeskik aan } \\
\text { status van vakdissiplines }\end{array}$ & $\begin{array}{l}\text { Samewerking: kennis van vakgebied } \\
\text { plus kommunikasie oor vakgebied } \\
\text { (Coetsee, Ter perse) }\end{array}$ & $\begin{array}{l}\text { Samewerking is ingewikkeld } \\
\text { en veeleisend, en geskied nie } \\
\text { sonder meer nie }\end{array}$ \\
\hline
\end{tabular}

In die gemelde artikel van Coetsee (Ter perse) word daar aangetoon in hoe 'n mate samewerking tussen AG-dosente en dosente uit die spesifieke vakgebiede soms tot gebrekkige kommunikasie en frustrasie kan lei. Hierdie artikel poog om Jacobs (2013) se argument een stap verder te voer wat betref samewerking tussen AG-spesialiste en vakspesialiste, eerder as om teoretiese insigte van vorige navorsing te repliseer.

\section{Ontwikkeling van praktyk}

Die probleemstelling vir hierdie studie is soos volg: In watter mate ondersteun die Taalsentrum die studente beter in lyn met teoretiese begronding as in die verlede? Die PIC-projek vir studente in die verlengde graadprogram word hier na as voorbeeld van suksesvolle intervensie van beter belyning tussen teorie en praktyk bespreek.

Die modules Wetenskapskommunikasievaardigheid 116 en 146 word in Afrikaans en Engels apart vir studente in die verlengde graadprogram van die Fakulteit Natuurwetenskappe en die Fakulteit Ingenieurswese aangebied. Sodanige studente word as 'n hoë risiko gesien aangesien hulle nie aan die basiese toelatingsvereistes van die US voldoen het nie, maar beskou word as potensieel in staat om wel met ekstra ondersteuning hulle studie suksesvol af te handel. 
Alhoewel die intensie om studente optimaal taalmatig te ondersteun reeds van die begin af vir hierdie modules gegeld het, was generiese kennis oor sake wat eerstejaars sou interesseer, grootliks die fokus van teksresepsie en -produksie in die verlede. Die uitkomste van hierdie spesifieke module (wat ses uur per week behels) was dus om studente in die verlengde graadprogram optimaal te ondersteun om in hulle ander modules (soos fisika- of wiskundemodules) akademies beter te lees en te skryf. Hierdie ses periodes per week word deur die Taalsentrum ten behoewe van die fakulteite aangebied en dit sluit min of meer 130 studente per jaar in (in 2017 was daar 30 Afrikaanse en 97 Engelse studente).

Om 'n mate van toepassing vir wetenskap- en ingenieurstudente in die verlengde graadprogram te fasiliteer, is die mielieprojek in 2010 geloods. Studente het drie mieliepitte in 'n houer geplant en moes dit versorg en toetse daarop uitvoer. Soos later gesien sal word (bylaag B), het studente hierdie projek egter nie deurgaans as 'n waardevolle intervensie beskou nie. Dosente se persepsie in 2010 dat studente meer skryfoefeninge oor algemene, generiese onderwerpe benodig, het verder veroorsaak dat studente oor verskeie onderwerpe benewens die mielieprojek moes skryf, daaroor geassesseer is en taaloefeninge moes afhandel om hulle 'taal te verbeter'.

Vier jaar gelede is daar in antwoord op teoretiese ontwikkeling egter besluit om 'n meer tersaaklike toepassing van teoretiese kennis aan te pak. Die mielieprojek is toe met die Pet Ionic Compound (PIC)-projek vervang. Die keuse van chemie vir 'n toegepaste projek het te make met hierdie vakgebied se 'hekwagterstatus' vir studente in die verlengde graadprogram. Een van die redes wat geïdentifiseer kan word waarom hierdie studente dikwels gesien word as hoërisikogevalle om nie hulle graadprogramme suksesvol af te handel nie, is hulle soms gebrekkige basiese kennis van byvoorbeeld chemie en wiskunde. Omdat chemie vertikaal georden is (Rootman-Le Grange et al., Voorgelê vir publikasie), is die suksesvolle bemeestering van basiese chemie-konsepte die voorvereiste vir daaropvolgende kennis. Die moontlikheid dat studente op skool boonop die verkeerde manier aangeleer het om chemie-kennis te bemeester (papegaaiwerk in plaas van begrip), veroorsaak dat hierdie vakgebied soms veral deur studente in die verlengde graadprogram as ernstig uitdagend ervaar word.

Die Pet Ionic Compound-projek (sien instruksies, bylaag A) is gekonseptualiseer as 'n toepassing van chemie-kennis met die doel om studente aan te moedig om individuele verbindings prakties te ondersoek. Vir die tweede iterasie het dosente in die vakgebied chemie die volgende uitkomste vir die projek bygevoeg:

- Dat jy wetenskap as 'n relevante, alledaagse verskynsel sal beskou

- Dat jy sal leer om die taal van die wetenskap te praat

- Dat jy die belang en posisie van die wetenskap in die gemeenskap sal verstaan

Die ingebedde deel daarvan wat wetenskapskommunikasie betref, het as uitkoms om wetenskap op gepaste wyse deur middel van akademiese tekste en aanbiedings te kan kommunikeer. Die relevansie van spesifiek chemie sou na verwagting die inkoop van studente verseker, terwyl die feit dat individuele ioniese verbindings ter sprake was, hopelik plagiaat sou ontmoedig.

Deur die iterasies van die PIC-projek oor die afgelope drie jaar is aansienlike verbeterings aangebring in die opdragte, die assesseringsmetodes en selfs in die leerplatforms waarop inligting geplaas is. Al hierdie veranderings is in pas met teoretiese verskuiwings aangepak. 
Voorbeelde hiervan is groter klem op koöperatiewe leer, 'n wegbeweeg van akademiese skryfwerk as enigste summatiewe assesseringsmiddel, en refleksie oor leer as aanmoediging tot hoërordedenke. Deur hierdie module se ontwikkeling te boekstaaf, word daar dus 'n waardevolle bydrae gelewer tot die praktiese toepassing van AG-teorie die afgelope paar jaar.

Voorheen, toe intervensies van AG-modules gebaseer was op gebrekkige vaardighede, was dit relatief eenvoudig om impakmeting te doen. ${ }^{2}$ 'n Voor- en natoets sou kwantitatief aantoon in watter mate studente gefasiliteerde vaardigheidsontwikkeling bemeester het. Intervensies het ook kwalitatief gefokus op persepsies van dosente oor wat studentebehoeftes en die vereistes van fakulteite was. ${ }^{3}$ Vir studente in die verlengde graadprogram was die impak van een intervensie vroeër selfs moeiliker om aan te toon, aangesien verskillende ondersteuningsintervensies (byvoorbeeld 'n ekstra module met die naam Universiteitspraktyk) aangewend is om studente optimaal te ondersteun.

Vir studente in die verlengde graadprogram is 'n slaagsyfer in alle modules 'n vereiste, insluitend in die wetenskapskommunikasie-module, aangesien hulle toegang tot die US daarvan afhanklik is. Indien hierdie module egter as van aansienlik minder belang as chemie of wiskunde beskou word, sal belangrike uitkomste soos gepaste wetenskapskommunikasie nie bereik word nie. Soos later (onder Bevindings oor studentepersepsies) aangetoon sal word, dra die besluit om 'n chemie-projek vir kommunikasievaardigheid te gebruik dus heelwat hoër gesag as die generiese opdragte van vroeër. In die literatuur is daar verder min samewerking tussen dosente in AG en chemie in Suid-Afrika geboekstaaf, wat hierdie studie se waarde verhoog.

Vervolgens word daar aangedui watter metodes aangewend is om studente en dosente se persepsies in verband met die belyning tussen die teorie en praktyk van AG kortliks voor te stel.

\section{Metodologie}

Vir hierdie studie is studente- en dosentetekste (evalueringsvorms, joernale en vraelyste) deur middel van oop kodering kwalitatief ondersoek om te identifiseer wat die belangrikste ontwikkeling in teorie en praktyk was in die afgelope ses jaar van die module Wetenskapskommunikasievaardigheid 146 se bestaan. Om na te gaan of hierdie module nou beter as voorheen belyn is met die teorie, is studente en dosente se positiewe en negatiewe opmerkings oor die Pet Ionic Compound-projek, wat die afgelope drie jaar die uitkomste van vaardighede in $\mathrm{AG}$ en chemie, inligtingsvaardighede en rekenaarvaardigheid probeer integreer het, tematies ondersoek. Etiese klaring vir die PIC-projek is verkry toe aansoek gedoen is vir befondsing uit die US se Innovasiefonds.

Daar is dus induktief omgegaan met die response van studente en dosente om breë temas uit die positiewe en negatiewe kommentaar op die PIC-projek te identifiseer. Kwantitatiewe impakmeting by die Departement Chemie en Polimeerwetenskap behoort volgens die outeur deur middel van voor-/natoetsing van inhoudskennis gedoen te word. Die voorkeur vir 'n kontinuum van impak in plaas van binêre slaag-/druippunte het ook sekere keuses gerig en

2 Spesifieke vaardighede is in die uitkomste van die modules gelys en studente is geïdentifiseer op grond daarvan of hulle hierdie vaardighede bemeester het al dan nie.

3 'n Voorbeeld hiervan waarby die outeur betrokke was, is onduidelikheid of ingenieurstudente in die verlengde graadprogram 'n tegniese verslag as genre moet aanleer of nie. 
ideaalgesproke moet impakmeting dus ook in samewerking met die dosente in die vakgebied chemie plaasvind. ${ }^{4}$

Alhoewel die outeur nog nie in 2010 by die program betrokke was nie, is studenteevalueringsvorms $^{5}$ (verkrygbaar by Institusionele Navorsing) vir Wetenskapskommunikasievaardigheid 146 met betrekking tot vier verskillende soorte data gekodeer:

1. Die studente se gemiddelde persepsies (telling uit 5) vir die mate waarin hulle denkvaardighede aangeleer het.

2. Die mate waartoe studente die module as relevant tot hulle programme gesien het.

3. Die gemiddelde persentasie wat die studente vir die module toegeken het na afloop van die module.

4. Wat oop antwoorde betref, is die opmerkings oor watter aspekte van hierdie module behoort te verbeter gekodeer (om studentetevredenheid al dan nie te meet). Breë temas is geïdentifiseer om die aantal response oor die tema vas te stel.

Studente het vir die afgelope drie iterasies van die PIC-projek ' $n$ joernaal ingedien as refleksie ${ }^{6}$ oor wat hulle daaruit geleer het. Kodering het weereens (soos hier bo) ingesluit om breë temas te identifiseer en die response te kwantifiseer. Rekenaarsagteware is nie hiervoor gebruik nie. Alhoewel joernale dus net vir die afgelope drie jaar gekodeer is, is die opmerkings vergelyk met dié oor die vorige projek (die mielieprojek) wat voorheen, soos nou, as uitkoms gestel het om studente die taal van wetenskap te leer kommunikeer.

Om dosente se persepsies oor verskille in teorie en praktyk te vergelyk, is 'n gestruktureerde fokusgroep georganiseer met vorige en huidige AG-dosente wat hierdie module onderrig (het) (sien bylaag $\mathrm{C}$ vir vrae, wat egter soos later verduidelik vir 'n vraelys gebruik is en ook na dosente in die vakgebied chemie en personeel van die biblioteek wat inligtingsvaardighede aangebied het, gestuur is). Aangesien AG-dosente ${ }^{7}$ egter by talle ander modules betrokke is, was die bywoning van hierdie fokusgroepe nie geslaagd nie en daar is besluit om die vrae eerder in 'n vraelys te omskep. Ongelukkig was al die vrae egter nie op al die dosente betrokke van toepassing nie (sommige was byvoorbeeld slegs een jaar, lank gelede, by Wetenskapskommunikasievaardigheid 146 betrokke en het nog nooit van die mielieprojek gehoor nie). Aanpassings moes gevolglik aan die vraelys gemaak word sodat spesifieke dosente (dié vir $\mathrm{AG}$, chemie en inligtingsvaardighede; $\mathrm{n}=8$ ) deel van die proses kon wees, wat weer veroorsaak het dat 'n groot deel van die data nie veralgemeen kon word nie.

Om op te som: die doel van hierdie studie, naamlik om die belyning van die teorie met die praktyk van AG-modules te ondersoek, is vir hierdie studie kwalitatief gedoen deur studenteen dosentepersepsies uit geskrewe tekste te kodeer. Ingesluit by die geïdentifiseerde tekste was evalueringsvorms (2010-2015) en reflektiewe joernale (2013-2016, vanaf die begin van die PIC-projek) deur studente in die verlengde graadprogram, asook die response van die betrokke

4 'n Gesamentlike artikel is oor hierdie projek geskryf en is in die publikasieproses.

5 Die US gebruik sodanige vorms aan die einde van modules om studente se persepsie oor onderrig vas te lê. Sommige dosente gebruik dit dus om materiaal, onderrigmetodes en belyning met uitkomste te verfyn.

6 Vir die waarde van reflektiewe leer, sien byvoorbeeld Granville en Dison (2005).

7 Vir 130 tot 150 studente per jaar, is daar in die verlede vyf groepe met een AG-dosent per groep gebruik. Sommige dosente was verskeie jare betrokke, maar vir studente in die verlengde graadprogram is daar in die verlede dikwels kontrakpersoneel gebruik. 
dosente (huidige sowel as voriges) op gestruktureerde vraelyste. Vervolgens word die bevindings bespreek.

\section{Bevindings oor studentepersepsies}

By die Taalsentrum is dit nie verpligtend dat studente alle modules aan die einde van semesters evalueer nie, aangesien studente soms verskeie evalueringsvorms moet invul (een vir elke module) en dus nie die invul daarvan met die nodige erns bejeën nie. Indien elektroniese vorms gebruik word, is dit ook nog nie gebruiklik om die invul daarvan verpligtend te maak as voorwaarde vir toetsaflegging nie. Omdat sommige dosente die vorms vir die laaste dag van die akademiese semester hou, is dit verder moontlik dat studente nie opdaag vir hierdie evaluering nie. Al die voornoemde redes beteken dat nie alle studente-terugvoervorms vir die tydperk 2010 tot 2016 ingedien is nie en daarom nie gekodeer kon word nie. Desnieteenstaande het die ondersoek na studentepersepsies uit hierdie bron vir 'n paar waardevolle insigte gesorg (sien bylaag B vir besonderhede).

Studentepersepsies van die geloofwaardigheid van Wetenskapskommunikasievaardigheid 146 (die gemiddelde persentasie wat studente op die vorm daaraan toegeken het) het van $67,5 \%$ (2010) tot 73,9\% (2016) gestyg. Studentepersepsies dat hulle denkvaardighede verbeter het, het egter min of meer dieselfde gebly (as antwoord op die stelling op die studentevalueringsvorm: "Hierdie module het my vaardighede in kritiese denke, analise en oplossing van probleme, kommunikasie, ens. help ontwikkel.") Hierdie response dui aan dat aktiwiteite voorheen wel as sinvol gesien is, maar dat latere ontwikkelings in denk- en kommunikasievaardighede (kernuitkomste van die module) volgens studentepersepsies meer waarde toegevoeg het.

Om te ondersoek of die voornoemde wel die geval is, is nog 'n stelling uit die evalueringsvorm longitudinaal nagegaan: "Die relevansie van hierdie module tot die program was vir my duidelik." Soos in bylaag B gesien kan word, het hierdie persepsie wel oor die tydperk wat ondersoek is verbeter. Studente ervaar dus dat dié module relevant is tot hulle wetenskaploopbaan, nou meer as voorheen.

Alhoewel die evalueringsvorm op die module in sy geheel fokus, is oop kodering slegs ten opsigte van die PIC-projek gedoen om die spesifieke impak daarvan te probeer meet. Aangesien negatiewe response op oop vrae aan die einde van die evalueringsvorms dikwels meer besonderhede as die positiewe response bevat, is daar besluit om dit soos volg te kodeer: Watter aspekte van die module Wetenskapskommunikasievaardigheid 146 kan verbeter? (2010-2016).

Soos uit die data (bylaag B) gesien kan word, was die studentekritiek aan die begin van Wetenskapskommunikasievaardigheid 146 (2010) op die vlak dat die werk meer prakties, interessant en relevant moet wees. Die mielieprojek ("Dis 'n nee-nee" volgens 'n 2011-student se opmerking) moes heelwat kritiek verduur, alhoewel dit oorspronklik juis aangepak is om die module meer prakties en interessant te maak. Die problematiek daarvan dat wetenskap- en ingenieurstudente totaal uiteenlopende vakgebiede bestudeer (van kernfisika tot toegepaste wiskunde, en van elektroniese ingenieurswese tot bewaringsekologie) maak die keuse van so 'n projek ook nie eenvoudig nie. Studentekritiek op die samewerking tussen dosente in die onderskeie departemente het ook tot veranderinge gelei. Met verloop van tyd het die oorspronklike studentekritiek oor relevansie en die teoretiese aard van die module egter plek gemaak vir kritiek oor tydsbestuur ("It is a heeluva [sic] lot of work for just 8 credits"). Die outeur sien hierdie kritiek as positief, alhoewel dit duidelik is uit die response dat studente nog 
nie samewerking tussen AG-dosente en dosente in die vakgebied chemie as positief vir hulle vakkennis en tydsbestuur sien nie. Alle studente sien dus nog nie hierdie projek as relevant en waardevol vir die vakgebied chemie én AG nie, alhoewel die feit dat 'n gedeelte van Wetenskapskommunikasievaardigheid 146 "ingebed" is in chemie (volgens AG-teorie) die relevansie van die module verbeter het.

Die kodering van studentejoernale van die afgelope drie jaar het sekere insigte na vore gebring. Die onderwerp waaroor studente moes skryf was: Wat het die PIC jou geleer? In die eerste iterasie is studente met kernwoorde aangemoedig om nie vaag te skryf nie. AG-fasiliteerders ${ }^{8}$ het byvoorbeeld genoem dat Bloom se taksonomie gebruik kan word om te ondersoek of studente insig openbaar in die ontwikkeling van hulle leerstrategieë al dan nie. Ongelukkig kon hierdie gestruktureerde studentejoernale volgens die literatuur oor reflektiewe leer nie vir oop kodering gebruik word nie. In daaropvolgende iterasies is geen instruksies gegee nie en punte is ook nie toegeken nie. Die temas (in volgorde van aantal response) wat studente aangedui het as temas wat leer aanmoedig, was soos volg:

Die meeste studente was positief dat hulle chemie-kennis aansienlik verbeter het. Hoe om bronne te soek en te gebruik is as tweede tema aangedui. Probleemoplossingsvaardighede en tydsbestuur, 'n grootliks onbedoelde uitkoms vir hierdie projek maar volgens die literatuur noodsaaklik (sien Van Dyk en Van der Slik 2012), is as verdere aspekte aangedui. Daarna was die kodes vir tegniese kennis (byvoorbeeld die workshop tool), prosesskryf, en groepwerk die belangrikste. Alhoewel daar nie 'n beduidende verskil tussen joernale vir die eerste en die derde iterasie was nie, is die instruksies (soos reeds verduidelik) verander en kan daar dus nie frekwensievergelykings getref word nie. "Hoe om wetenskaplik te skryf" is ongelukkig selde verbatum aangedui in die joernale. Die voornoemde temas word nou met behulp van spesifieke voorbeelde bespreek.

Studentepersepsies oor die waarde van die PIC-projek, alhoewel dit nie met behulp van kwantitatiewe impakmeting ondersoek is nie, het bykans deur die bank bevestig dat die gestelde uitkomste van AG en chemie behaal is. Wat die ontwikkeling van chemie-kennis betref, was studente dit eens dat die toepassing van teoretiese kennis uit handboeke 'n positiewe impak op dieper leer en liefde vir die vakgebied het.

"The chemistry life is not as complicated as I expected but easy only if you find much information which builds love, passion and as a result, hunger for chemistry" (MM 2016).

Alle studente was egter nie so positief oor die toename in hulle chemie-kennis nie:

"After a tedious and extensive search my knowledge expanded slightly" (AC 2016).

Ontwikkeling van 'n eie wetenskaplike stem: ${ }^{9}$

"It has become clear that through all my years of school I was guilty of blatant plagiarism" (NM 2015).

8 Alhoewel AG-fasiliteerders in hierdie artikel dosente genoem word om hulle status te verhoog, is daar volgens die teoretiese begronding van Wetenskapskommunikasievaardigheid 146 geen sprake van formele onderrig of doseer nie.

9 Aangesien die Afrikaanse gedeelte van hierdie module-kohort aansienlik kleiner as die Engelse deel is, is Engelse response ook gekodeer en in berekening gebring, maar nie vertaal nie. 
Hierdie aspek word gesien as 'n belangrike uitkoms wat dikwels in geen ander vakgebied as AG aangespreek word nie, aangesien studente nie in wiskunde of fisika geskikte bronne soek en daaroor skryf nie.

Verbeterde deelname aan koöperatiewe leer: "In the future I would suggest that peer assessors should sit down with the people and tell them where they went wrong and in turn that would also help them better their understandings of the specific topic addressed" (NP 2015). Studente se aktiewe meewerking in die proses van eweknie-assessering bewys dat ware eienaarskap van leer (ook koöperatiewe leer) by sommige studente plaasgevind het. Volgens die ontwikkeling van AG-teorie as individuele vaardigheidsonderrig tot sosiale induksie is hierdie aspek beduidend.

Sekere onbedoelde effekte van die projek word as positief gesien, alhoewel dit nie spesifiek met die gestelde uitkomste van Wetenskapskommunikasievaardigheid 146 belyn is nie, maar slegs as voorkeurgraduandi-eienskappe aangedui kan word.

"My greatest benefit from this project is that it helped me improve on my work ethic" (CJ 2016).

'n Tweede afdeling van hierdie studie het as doel gehad om ondersoek in te stel daarna of die teoretiese ontwikkeling oor AG 'n positiewe impak gehad het op die manier waarop dosente (van die Taalsentrum en die Fakulteit Natuurwetenskappe) oor hulle onderrig en studentesukses reflekteer, met ander woorde of dosente tevrede is dat hulle professioneel op grond van teoretiese benaderings optree en hulle studente optimaal ondersteun. ${ }^{10}$

\section{Bevindings oor dosentepersepsies}

Dosentepersepsies oor die PIC-projek is hoofsaaklik ondersoek met die doel om te verseker dat die deelnemende dosente (slegs altesaam agt uit die verskillende omgewings het die vraelyste ingevul) die belyning tussen teorie, uitkomste, klasaktiwiteite en assessering verstaan en toepas (sien bylaag $\mathrm{C}$ vir vraelys aan dosente). Die oorspronklike plan, naamlik om gestruktureerde fokusgroepe vir dosente te organiseer, is met verloop van tyd met gestruktureerde vraelyste vervang, meestal as gevolg van die ekonomie van skaal, waarvolgens AG-dosente by verskeie ander modules betrokke is.

Die outeur het mettertyd besef dat dit moeilik is om vorige en huidige dosente, asook AGdosente, dosente van die Departement Chemie en Polimeerwetenskap betrokke by die vakgebied chemie en personeel van die biblioteek wat inligtingsvaardighede aangebied het, in dieselfde vraelys te betrek. Die vraelys moes daarom vir verskillende teikenlesers aangepas word (soos kommunikasieteorie ook voorskryf), wat die ingesamelde data minder geskik vir veralgemening maak. Om die teorie van samewerking (Jacobs 2013) tussen AG en chemie te verdiskonteer, moes die impak van die PIC-projek op dosente uit ander omgewings ook in ag geneem word.

10 Hierdie afdeling is belangrik vir die konsep van onderrig as wederkerige aktiwiteit, en nie net vir dosentstudent-interaksie nie. Dié fokus is die afgelope tyd in die AG-teorie weerspieël. Tydens die eerstesemestermodule van Wetenskapskommunikasievaardigheid 116 word daar meer op persepsies van studente se behoefte aan tweedetaalintervensie gefokus, wat die rede is waarom studentebehoeftes nie hier bespreek word nie. 
Die teoretiese vereiste dat klaskamerintervensie met AG-teorie belyn moet wees, is oor die algemeen nie deur AG- en chemie-dosente as belangrik beskou nie. Boonop was dit vir AGdosente moeilik om in die geval van die PIC-projek in die rigting van ingebedde modules te beweeg vanweë onvoldoende chemie-kennis en die persepsie dat Taalsentrumpersoneel nie kommunikasie in verband met chemie kan onderrig of assesseer sonder voldoende chemiekennis nie. Hieruit blyk dit dat die status van AG as wetenskap en area van deskundigheid selfs onder AG-dosente as aansienlik laer as dié van chemie beskou is.

Die agt dosente in die steekproef was bykans almal van mening dat die volgende aspekte sedert 2010 (nie almal was toe reeds betrokke by Wetenskapskommunikasievaardigheid 146 nie) verfyn is:

1. Die PIC-projek as toepassing van vakkennis

2. Die uitkomste van $A G$

3. Samewerking tussen die Taalsentrum en fakulteite

Die dosente was verder van mening dat die Taalsentrum slegs op behoeftes wat deur die fakulteite uitgespreek is, kon reageer. Dit beteken dat uitkomste in die verlede gestel is deur dosente wat nie deskundiges was op die gebied van geletterdhede nie en ook nie begrip van die ontwikkeling van teoretiese benaderings gehad het nie. Samewerking tussen Taalsentrumpersoneel en fakulteitspersoneel verhoog die status van AG-fasiliteerders, soos dit ook in die teorie hieroor gestel word.

\section{Gevolgtrekking en slot}

Studente sien die ondersteuning wat die Taalsentrum hulle ten opsigte van AG bied, toenemend as waardevol. Onder andere is die persentasie wat hulle aan die module toeken op evalueringsvorms tans duidelik meer as in die verlede. Aangesien intervensies in byvoorbeeld chemie- en ander vakkennis ingebed is, is studente se persepsie (soos blyk uit die reflektiewe joernaalinskrywings) ook dat dit van toepassing op hulle gekose studieprogramme is, en nie bloot aparte kennis wat irrelevant tot hulle toekoms is nie.

Wat die persepsies van dosente betref: kundigheid oor die teoretiese benaderings wat behoort te dien as begronding vir die praktyk van akademiesegeletterdheid-fasilitering is deur die vraelys wat hierdie studie gebruik het as onvoldoende uitgewys (soos reeds in 2007 tydens navorsing deur Jacobs bevind). Dat personeeltoedeling by die Taalsentrum beter opgeleide fasiliteerders behoort uit te maak, is dus een van die voorstelle van hierdie studie.

Onvoldoende teoretiese kennis van kollegas oor ontwikkelings het na hierdie outeur se mening 'n impak op studentesukses en op die Taalsentrum se vermoë om die klaspraktyk vir AG na behore te begrond. Een bewys vir hierdie mening is die feit dat sommige kollegas (in fakulteite en vir AG) die agterhaalde benadering volg dat die Taalsentrum bloot reageer op fakulteite se gestelde verwagtings. Vir die toekoms van Wetenskapskommunikasievaardigheid 146 en soortgelyke modules elders word die volgende in die vooruitsig gestel: selfs beter begronding van die praktyk na aanleiding van die teorie, beter belyning tussen al die aspekte hier bo ter sprake, en beter samewerking tussen die Taalsentrum en vakspesialiste in die fakulteite. Slegs dan sal ontwikkelings met betrekking tot AG-teorie die impak hê wat studentesukses verseker en aan dosente verdiende werksbevrediging besorg. 


\section{Bronnelys}

Boughey, C. 2013. What are we thinking of? A critical overview of approaches to developing academic literacy in South African higher education. Journal for Language Teaching 47(2): 25-42.

Boughey, C. en S. McKenna. 2016. Academic literacy and the decontextualised learner. Critical Studies in Teaching and Learning 4(2): 1-9.

Carstens, A. 2013. Collaboration as the key to integration of language and content in academic literacy interventions. SA Journal for Language Teaching 47(2): 109-126.

Coetsee, Y.C. Ter perse. Some challenges of collaboration between academic literacies and subject specialists: Framing the difference. Per Linguam.

Cummins, J. 2008. BICS and CALP: Empirical and theoretical status of the distinction. In B.V. Street en N. Hornberger (reds.) Encyclopedia of language and education, Volume 2: Literacy. 2de uitgawe. New York: Springer Science + Business Media LLC. pp. 71-83.

French, A. 2011. 'What am I expecting and why?' How can lecturers in higher education begin to address writing development for their students? Journal of Academic Writing 1(1): 228-238.

Gee, J.P. 1996. Social Linguistics and literacies: Ideology in discourses. 2de uitgawe. Londen: Taylor \& Francis.

Granville, S. en L. Dison. 2005. Thinking about thinking: Integrating self-reflection into an academic literacy course. Journal of English of Academic Purposes 4(2): 99-118.

Henderson, R. en E. Hirst. 2007. Reframing academic literacy: Re-examining a short-course for "disadvantaged" tertiary students. English Teaching: Practice and Critique 6(2): 25-38.

Hirst, E., R. Henderson, M. Allan, J. Bode, en M. Kocatepe. 2004. Repositioning academic literacy: Charting the emergence of a community of practice. Australian Journal of Language and Literacy 27(1): 66-80.

Jacobs, C. 2007. Mainstreaming academic literacy teaching: Implications for how academic development understand its work in higher education. South African Journal of Higher Education 21(7): 870-881.

Jacobs, C. 2009. Teaching explicitly that which is tacit: The challenge of disciplinary discourses. In Leibowitz, B., A. van der Merwe en S. van Schalkwyk (reds.) Focus on first-year success: Perspectives emerging from South Africa and beyond. Stellenbosch: SUN Media. pp. 241-252.

Jacobs, C. 2010. Collaboration as pedagogy: Consequences and implication for partnerships between communication and disciplinary specialists. Southern African Linguistics and Applied Language Studies 28(3): 227-237.

Jacobs, C. 2013. Academic literacies and the question of knowledge. Tydskrif vir Taalonderrig 47(2): 127-140.

Lea, M.R. 2004. Academic literacies: A pedagogy for course design. Studies in Higher Education 29(6): 739-756.

Lea, M.R. en B.V. Street. 2006. The academic literacies model: Theory and applications. Theory into Practice 45(4): 368-377. 
Lillis, T. en M. Scott. 2007. Defining academic literacies research: Issues of epistemology, ideology and strategy. Journal of Applied Linguistics 4(1): 5-32.

Rootman-Le Grange, I., E. Jacobs, H. Adendorf, H. Retief en Y.C. Coetsee. Voorgelê vir publikasie. An interdisciplinary project between chemistry and scientific communication: A case study.

Smit, R. 2012. Towards a clearer understanding of student disadvantage in higher education: Problematizing deficit thinking. Higher Education Research \& Development 31(1): 369-380.

Van Dyk, T.J., K. Cillie, M. Coetzee, S. Ross en H. Zybrands. 2011. Ondersoek na die impak van 'n akademiese geletterdheidsintervensie op eerstejaarstudente se taalvermoë. LitNet Akademies 8(3): 487-506.

Van Dyk, T.J. en F.W.P. van der Slik. 2012. Dalende akademiese geletterdheidsvlakke: Feit of fiksie? Tydskrif vir Taalonderrig 46(2): 43-55.

Weideman, A. 2003. Assessing and developing academic literacy. Per Linguam 19(1\&2): 55-65.

Wolff, D. 2003. Integrating language and content in the language classroom: Are transfer of knowledge and of language ensured? ASp 41-42: 35-46. 


\section{Bylaag A: PIC-projek instruksies (2017-weergawe)}

\section{The Pet Ionic Compound Project (PIC project) ${ }^{11}$}

The PIC project is an interdisciplinary project that brings together Chemistry, Scientific Communication (SciComm) and Computer Skills. The purpose of the project is for you to experience some of the concepts we will be introducing during chemistry lectures, in a fun and explorative manner. Furthermore, the project strives to provide a context where you can apply and develop some of the vital skills that you acquire in both SciComm and Computer Skills modules.

PIC stands for Pet Ionic Compound and refers to the unique ionic compound on which you will conduct your project. As we work through new concepts during lectures you will use the knowledge you gain to gather information on your unique PIC. You should also be on the lookout for traits that may be unique to your PIC, 'things' that make it stand out from the rest of the class. You may even call for an opportunity during a tutorial session to boast about these unique traits. These traits will give you a big advantage during the final presentations of the projects.

The PIC project runs from the second till the fourth term. For each of the assignments you will submit a short report on SUNLearn. For some predetermined assignments you will submit an additional hard copy of the report to your SciComm lecturer. These reports will be graded according to their rules ${ }^{12}$. You will receive continuous feedback on all your assignments, either from your lecturers or through peer assessment.

At the end of the year each subgroup will identify their PIC that has the most interesting and unique characteristics. Each subgroup will then do a presentation in SciComm on this PIC. From these presentations the SciComm class will identify their favourite PICs to compete in a 'brag'-session where the six subgroups to whom these PICs belong will have the opportunity to battle it out to claim the title of PIC champion.

Since both the presentations and the brag-session will be a group effort, you cannot focus only on your own report. During the year you will also have to oversee and advise on the PICs of your subgroup members, to ensure that one of your PICs stand a chance to win the title.

\section{Questions and support:}

For any general queries regarding the PIC project, post a question on the PIC frequently asked questions (FAQ) board on SUNLearn. For queries directly relating to an assignment, contact the appropriate lecturer.

Mrs. Coetsee is the project coordinator for the PIC project. She can be contacted through the PIC SUNLearn module or by email (yc@sun.ac.za). For any Chemistry related questions related to your PIC contact Dr. Pretorius (pretoriusc@sun.ac.za) and for any resource related queries contact your faculty librarian, Ms. Theron (theronm@sun.ac.za)

11 Hierdie projek word in Afrikaans en Engels apart aangebied, aangesien die Universiteit veeltalig funksioneer.

12 Hierdie nadruk is aangedui (deur die outeur) om te demonstreer in hoe 'n mate ware samewerking geskied het. 


\section{Outcomes:}

- that you will experience science as a relevant and everyday phenomenon

- that you will learn to talk the language of science

- that you will understand the importance and position of science in society

\section{Rules for choosing PICs:}

You must construct your PIC according to the rules below.

1. No two students in a particular chemistry class may have the same PIC. Duplication of a cation or anion is however allowed, as long as it is not in the same subgroup. There could for example be a number of PICs containing titanium(IV) cations, but each one will have to be paired with a different anion and it must be in different subgroups.

2. The PIC is registered in your name on a first-come-first-serve basis.

3. The cation of your PIC may not be a group 1 metal. Metals in periods 2, 3, and 4 of group 2 are also not allowed.

4. Cations from the same element, but of different oxidation states are considered different e.g. chromium(III) nitride and chromium(IV) nitride are considered different PICs.

5. The anion may be monatomic or polyatomic, but it may not be the conjugate base of anyone of the seven strong acids. 


\section{Project outline:}

\begin{tabular}{|c|c|c|}
\hline $\mathbf{N r}$ & Assignment/Event & Preliminary deadlines \\
\hline 0 & Introduction session: The project will be introduced and explained in class. & 3 April \\
\hline 1 & $\begin{array}{l}\text { Assignment: Give the formula and systematic name of your PIC. Also pair } \\
\text { your cation and anion respectively with any five other cations and any five } \\
\text { other anions. You should now have } 10 \text { additional ionic compounds which you } \\
\text { must name and write the formulas of. We will refer to these compounds as } \\
\text { companion compounds in later exercises. Write a coherent paragraph } \\
\text { explaining how you went about naming the above compounds, by referring to } \\
\text { the rules for naming of ionic compounds. }\end{array}$ & $\begin{array}{l}\text { Submit: } 19 \text { April } \\
\text { Peer assess: } 23 \text { April }\end{array}$ \\
\hline 2 & $\begin{array}{l}\text { Assignment: Assuming that your PIC and its companion compounds are } \\
\text { completely soluble in water, write dissociation reactions for your PIC and at } \\
\text { least five of its companion compounds. Also calculate the molarity of the } \\
\text { solution if } 25.0 \mathrm{~g} \text { of your PIC is dissolved in enough water to make up a } 250 \\
\text { ml solution? Repeat the exercise with each of the five companion compounds } \\
\text { identified above. Finally, rank the concentrations of the six compounds from } \\
\text { smallest to largest and write a coherent paragraph explaining the outcome of } \\
\text { these calculations. }\end{array}$ & $\begin{array}{l}\text { Submit: } 12 \text { May } \\
\text { Peer assess: } 26 \text { May }\end{array}$ \\
\hline 3 & A comprehension test on the project brief & In class \\
\hline 4 & $\begin{array}{l}\text { Assignment: Write a coherent summary }{ }^{13} \text { (not more than one page) of about } \\
300 \text { words about the following: } \\
\text { Your PIC is made up of different elements: when, where and by whom was } \\
\text { each of these elements discovered? Where do the names of these elements } \\
\text { come from? }\end{array}$ & $\begin{array}{l}\text { Submit: } 21 \mathrm{Jul}^{*} \\
2^{\text {nd }} \text { Submission: } 13 \text { Oct }\end{array}$ \\
\hline 5 & $\begin{array}{l}\text { Assignment: In order to compare PICs you need to find information about its } \\
\text { industrial value. (What can it be used for?) Write a -summary (not more than } \\
\text { one page) of } 200 \text { words about this topic. }\end{array}$ & \begin{tabular}{|l} 
Submit: 31 Jul* \\
$2^{\text {nd }}$ Submission: 13 Oct
\end{tabular} \\
\hline 6 & $\begin{array}{l}\text { Assignment: Will you suffer adversely if you ingest your PIC? Write a short } \\
\text { report (200-300 words) detailing the toxicity of your cation or anion or both. }\end{array}$ & $\begin{array}{l}\text { Submit: } 8 \text { Aug* } \\
2^{\text {nd }} \text { Submission: } 13 \text { Oct }\end{array}$ \\
\hline 7 & $\begin{array}{l}\text { Assignment: Write a hydrolysis reaction for your anion in water. Calculate the } \\
\mathrm{pH} \text { of the solution that will form if you were to dissolve } 25.0 \mathrm{~g} \text { of the sodium } \\
\text { salt of your anion in pure water to make a } 500 \mathrm{~mL} \text { solution at } 25^{\circ} \mathrm{C} \text {. Do you } \\
\text { think a solution of your PIC in water will be acidic, basic or neutral? Explain } \\
\text { why, by also referring to the nature of your cation. }\end{array}$ & $\begin{array}{l}\text { Submit: } 15 \text { Sept } \\
\text { Peer assess: } 29 \text { Sept }\end{array}$ \\
\hline 8 & Assignment: Write an abstract for SciComm. & Submit: 28 Sep* \\
\hline 9 & Make presentations in subgroups in Computer Skills. & $26 \mathrm{Sept}-7 \mathrm{Oct}$ \\
\hline 10 & Assignment: Write a journal entry about the PIC project (Reflection exercise). & Submit 13 Oct* \\
\hline 11 & Give group presentations to SciComm. & \begin{tabular}{|l|} 
In class: \\
Week of 10 Oct
\end{tabular} \\
\hline 12 & Boasting session & In class: 19 Oct \\
\hline
\end{tabular}

All assignments must be uploaded on SUNLearn. For assignments marked with an asterisk* an additional hard copy must be handed in to your SciComm lecturer by the same deadline.

13 Hierdie nadruk (deur die outeur) demonstreer dat die Taalsentrum met die instruksies betrokke was. 


\section{Bylaag B: Response op student-evalueringsvorms}

\begin{tabular}{|c|c|c|c|c|c|c|}
\hline Jaar & $\begin{array}{c}\text { Aantal } \\
\text { studente } \\
\text { wat vorm } \\
\text { invul }\end{array}$ & $\begin{array}{l}\% \text { ander } \\
\text { tale }\end{array}$ & $\begin{array}{c}\% \text { vir } \\
\text { SciComm } \\
146\end{array}$ & $\begin{array}{l}\text { Persepsie } \\
\text { relevansie }\end{array}$ & $\begin{array}{c}\text { Persepsie } \\
\text { denk- } \\
\text { vaardighede }\end{array}$ & $\begin{array}{c}\text { Wat moet verander? (in volgorde } \\
\text { van getal response) }\end{array}$ \\
\hline 2010 & $\mathrm{n}=91 / 154$ & $22>24 \%$ & 67.5 & 3.9 & $3.8 / 5$ & $\begin{array}{l}\text { Meer interessante }{ }^{14} \text { opdragte } \\
\text { Moet meer prakties wees } \\
\text { Content a bit unnecessary } \\
\text { Assessments should be more } \\
\text { challenging }\end{array}$ \\
\hline 2011 & $n=101 / 129$ & $25>24 \%$ & 69.8 & 3.8 & 3.6 & $\begin{array}{l}\text { More interesting tasks } \\
\text { The mealie project } \\
\text { The relevancy to our course x } 2 \\
\text { Tipe werk wat gedoen word } \\
\text { The textbook is vague } \\
\text { Communication with other modules } \\
\text { "Die mielie-projek. Dis 'n nee-nee." }\end{array}$ \\
\hline 2012 & $\mathrm{n}=64 / 148$ & $19>29 \%$ & 72.4 & 4.0 & 3.8 & $\begin{array}{l}\text { Mealie research project } \\
\text { Relevance towards science field } \\
\text { Course needs to take itself more } \\
\text { seriously } \\
\text { Big project not FUN }\end{array}$ \\
\hline 2013 & $\mathrm{n}=73 / 149$ & $20>27 \%$ & 72.2 & 4.1 & 4.0 & $\begin{array}{l}\text { They need to improve the project } \\
\text { (mielie) } \\
\text { More engineering topics } \\
\text { More challenging work < slower } \\
\text { pace } \\
\text { Make it a bit interesting }\end{array}$ \\
\hline 2014 & $\mathrm{n}=127 / 187$ & $32>25 \%$ & 72.7 & 4.2 & 3.9 & $\begin{array}{l}\text { Communication faculties } \\
\text { Instructions PIC } \\
\text { More relevance Engineering } \\
\text { Dit moet meer met ander modules } \\
\text { kontak maak, soos met Chemie } 176 \\
\text { More fun }\end{array}$ \\
\hline 2015 & $\mathrm{n}=70 / 151$ & $10>14 \%$ & 73.9 & 4.1 & 4.0 & $\begin{array}{l}\text { "It is a heeluva (sic) lot of work for } \\
\text { just } 8 \text { credits." }\end{array}$ \\
\hline
\end{tabular}

14 Skuinsdruk is gebruik om aan te toon dat studente nie tevrede was met die status quo van hierdie module nie. 
Bylaag C: Gestruktureerde vraelys aan dosente (AG-dosente, dosente in die vakgebied chemie en personeel van die biblioteek wat inligtingsvaardighede aangebied het)

1. Gee u opinie van die WKV-module 146 op 'n skaal van $0=$ laag tot $5=$ hoog. Rede vir u keuse:

2. Wat dink $\mathrm{u}$ is die studente se persepsie van die module?

Wat dink u was die studente se persepsie van die Mielie-projek? (indien van toepassing)

3. Hoe voel $\mathrm{u}$ oor die samewerking tussen die Taalsentrum en die Natuurwetenskapkollegas? $(2010>$ nou $)$

4. Wat is $u$ verstaan van die teoretiese begronding van die Akademiese Geletterdheidsmodule SciComm 146 ...

4.1 in die verlede?

4.2 tans?

5. Watter impak het hierdie teoretiese begronding op ons ...

5.1 keuse van tekste en genres vir resepsie en produksie?

5.2 keuse van formatiewe en summatiewe assessering?

5.3 samewerking met kollegas in vakgebiede?

5.4 studente-evaluering?

6. Was daar in die verlede/Is daar tans goeie belyning tussen die Teorie, Uitkomste van die module, Klasaktiwiteite en Assesserings? $(0=$ geen belyning, $5=$ goeie belyning $)$ Rede vir u keuse?

7. Wat is na u mening die belangrikste uitkomste van WKV 146? Hoekom? 